\title{
Physicochemical Properties of Briquettes from Different Feed Stock
}

\author{
D. K. VYAS' ${ }^{1}$, F.G. SAYYAD ${ }^{1}$, M.S. KHARDIWAR ${ }^{2}$ and SHAILENDRA KUMAR ${ }^{2}$ \\ 1'Department of AP \& FE, CAET, Anand Agricultural University, Godhra, Gujarat , India. \\ 2Polytechnic in Agricultural Engineering, Anand Agricultural University, Dahod, Gujarat, India. \\ http://dx.doi.org/10.12944/CWE.10.1.32
}

(Received: Feburary 11, 2015; Accepted: April 08, 2015)

\begin{abstract}
This study was undertaken to evaluate the Physico-chemical properties of eight different types of biomass feedstock and their briquettes were studied among that some properties which are influence their storage and combustion properties like Equilibrium moisture content (EMC \%) and Relative humidity (\%). Equilibrium moisture content are found out by static equilibrium technique using aqueous glycerol solutions of different concentrations in the relative humidity $(R H)$ range of 40 to $90 \%$ and at ambient temperature between 25 to $37 \stackrel{\circ}{\circ}$. The Equilibrium moisture content of briquettes was lower than their feedstock by about $1-2.5 \%$ in all the cases ranges from 40 to 70 $\% \mathrm{RH}$. At higher $\mathrm{RH}$ above $70 \%$, the difference was between 2 - 4\%. There was no change in the shape of the briquettes at all levels of $\mathrm{RH}$. This was due to higher density of briquettes. This study showed during period of high humidity, the storage of briquettes will not create any problem and will be safer as compared to their feedstock.
\end{abstract}

Key words: Biomass feedstocks, EMC of biomass and briquettes, Relative humidity.

\section{INTRODUCTION}

With respect to global issues of sustainable energy and reduction in greenhouse gases, biomass energy as one of the key sources of renewable energy is boon as a potential source of energy in the future. In India generally agricultural residue such as rice husk, cotton stalks, soybean stalks, pigeon pea stalk, groundnut shell, safflower residue etc. are available in abundant quantity. It was reported that 15-50 per cent of the worlds primary energy used could come from biomass by the year 2050. Currently about 11 per cent of the worlds primary energy is estimated to be met with biomass (Tripathi, 2009). The accessibility of biomass in India is estimated at about 500 million metric tonnes per year. It is estimated that the surplus biomass availability at about $120-150$ million metric tonnes per annum covering agricultural and forestry residues corresponding to a potential of about $18,000 \mathrm{MW}$.
This apart, about $5000 \mathrm{MW}$ additional power could be generated through baggase based cogeneration in the country's 550 Sugar mills, if these sugar mills were to adopt technically and economically optimal levels of cogeneration for extracting power from the baggase produced by them. In future further increasing need and demand for energy; especially electrical power energy (www.mnre.gov.in).

Biomass materials are hygroscopic in nature. Grains, straw, stalks, hulls, shells, saw dust, sugarcane baggase, dry leaves, etc. are all hygroscopic in nature and release moisture with the change in temperature and relative humidity conditions. This characteristic of biomass is important for the design of storage structures, dryers, estimation of storage life of materials etc. Proper and accurate knowledge of EMC is beneficial from the point of view of either manipulating environmental conditions during the storage of materials or taking 
pre-conditioning measures to insure that the material is not spoiled during storage under high humidity conditions. The proposed research work is to carried out with the specific objectives of to determine the equilibrium moisture content of biomass feedstock and their briquettes and results are discussed.

The unused pine needles from the forests in the state of Uttarakhand amount to $1.8 \mathrm{MT}$, says the state forest department. If this quantity can be properly briquetted, it can produce approximately $5940000 \mathrm{MW}$ of energy every year. It will result in enormous $\mathrm{CO}_{2}$ savings. For instance, $1.3 \mathrm{t}$ of biomass briquettes replaces $1 \mathrm{t}$ of coal used by brick kiln, saving of $1.81 \mathrm{t}$ of $\mathrm{CO}_{2}$ emissions and 2.5 $\mathrm{t}$ of biomass briquettes replaces $1 \mathrm{t}$ of LPG, saving $2.98 \mathrm{t}$ of $\mathrm{CO}_{2}$ emission. The properties of briquettes produced from corn cob and rice husk residues with a view for finding out most efficiently fuel among above. Among the positive attributes of agro -waste briquettes are low moisture content, high crushing strength, high density, slow flame propagation, low ash content, high amount of hydrogen and substantial heating value (Oladeji,2010).

\section{Properties of biomass briquettes}

Physical and chemical properties of crop residues and its briquette are obviously the most vital parameter, which decides the consistent and efficient operation of the gasifier, important to decide suitability for briquetting and quality of briquettes, respectively (Khardiwar et al. 2014)

\section{Moisture content}

The moisture content plays vital role in the formation of briquette and subsequently its combustion. Moisture content of biomass at the time of harvesting varies drastically. The downdraft gasifiers are limited to biomass fuels with moisture content below 20 per cent (Payne 1986). Ash content of sugarcane stem top leaves observed $15-29$ per cent; heating values are proportional to volatile concentration and inversely proportional to ash content. Fixed carbon of all residues was observed above per cent. Ultimate analysis gives the carbon, hydrogen, oxygen and nitrogen percentage in agro residues. It was observed that carbon content is directly proportional to heating value (Khan, 1993).
Low heat value of fuel has direct relation to its moisture content which affect the efficiency of boiler. The price of fuel is settled on the basis of man factors like calorific value of fuel moisture content and ash content etc. Results suggested that the compressive strength and shatter index were increased with increasing in the moisture content of briquettes samples significantly. To facilitate stable compaction, MC was found to lie in between 13 and 18 per cent by weight. The effect of moisture content of the briquettes is control by the machine and mixture factor (Demirbas, et.al 2004).

\section{Bulk Density}

The physical properties like bulk density, moisture content and average particle size of the raw material affects their briquetting properties (Wakchaure and Sharma 2007).

\section{Chemical properties of crop residues briquette}

Chemical properties are very important to determine the fuel quality. Study of proximate analysis of biomass was carried out for determination of volatile matter, fixed carbon, ash content, Ash fusion temperature and Calorific value, in the biomass.

\section{Volatile matter}

Volatile matter is that portion of fuel, which is driven off in the form of gas or vapour when subjected to control heating. Volatile matter consists of hydrocarbons and other gases resulting from distillation and decomposition of residues.

\section{Ash content}

Its properties have an impact on the combustion systems. Ash is the non-combustible residue left after complete combustion. The biomass fuels particularly wood derived fuels are low in ash but several biomass fuels contain large quantities of ash that makes their combustion or stationary bed gasification difficult (Payne, 1986).

Briquetting of agro residues suitable for gasification was studied and determined ash content of some biomass. The rice husk contains highest percentage of ash content and saw dust contain lowest among selected biomass (Shrivastava, 2009). 


\section{MATERIALS AND METHODS}

\section{Moisture content}

The moisture content of biomass was measured by oven dry method. Initially the sample with the known weight was kept in oven at $105^{\circ} \mathrm{C}$ for 24 hours. The oven dry sample is then weighed (Browning, 1967). The moisture content of sample was calculated by following formula.

$$
\text { M.C. }=\frac{\mathrm{W}_{1}-\mathrm{W}_{2}}{\mathrm{~W}_{1}} \times 100
$$

Where,

$\mathrm{MC}=$ Moisture Content

$\mathrm{W}_{1}=$ Weight of sample before drying, $\mathrm{g}$

$\mathrm{W}_{2}=$ Weight of sample after drying, $\mathrm{g}$

\section{Bulk density}

The standard Water displacement method was used to measure the volume of individual briquette. (Tayade, 2009).

$$
(\text { Bulkdensity })=\frac{\text { Mass } \phi \text { samples }}{\text { Volume } \oint \text { sample taken }}
$$

Chemical Parameter of crop residues briquette

The ASTM D 3172, ASTM D 3177, ASTM D 3175, ASTM D 1875, ASTM D 3286 was used for the study.

\section{Volatile matter}

The same sample from previous determination of moisture content is used for percentage of volatile matter and it is determined by using the following formula (ASTM, 2012).

$$
\text { volatile matter, } \%=\frac{b-c}{a} \times 100
$$

Where,

$\mathrm{a}=$ initial weight of sample, $1 \mathrm{~g}$.

$\mathrm{b}=$ final weight of sample after cooling

(Heating temperature $107 \pm 3^{\circ} \mathrm{C}$ for 1 hour).

$\mathrm{c}=$ final weight of sample after cooling

(Heating temperature $950 \pm 20^{\circ} \mathrm{C}$ ).

Fixed carbon

The residue remaining after volatile matter release has been expelled, contains the mineral matter originally present and non volatile or fixed carbon. The fixed carbon was thus calculated as follows (Jenkins, et al. 1998).
Fixed Carbon(\%)=100-(\% moisture+\%Ash+\%VM)

\section{Ash content}

The same sample from previous determination of volatile matter content is used to determine the percentage of Ash content. The sample from in the crucible was then heated without lid in a muffle furnace at $700 \pm 50^{\circ} \mathrm{C}$ for an hour the crucible was then taken out, cooled first in air, then in desiccators and weighed. Heating, cooling and weighing is repeated till a constant weight is obtained. The residue was reported as ash on per cent basis. Percentage of ash is determined by using the following formula (Rabier et al., 2006).

$\% \oint$ ash $=\frac{\text { Weight } \varnothing \text { ash left }}{\text { Weight } \phi \text { sample taken }} \times 100$

\section{Ash fusion temperature}

The standard tests for fusibility of coal and coke ash are based on ASTM D-1875. The biomass is dried, ground, and placed in the muffle furnace at $750^{\circ} \mathrm{C}$ in the atmosphere of air till constant weight is obtained. The residual ash is then finely ground a solution containing $10 \%$ dextrin, $0.1 \%$ salicylic acid and $89.9 \% \mathrm{H}_{2} \mathrm{O}$ by weight, is added to ash. To make it a plastic mass, the mass is moulded to a cone shape by pressing it into a suitable mould. These cones are taken out and allowed to dry. The dry cones placed on a refectory base are then inserted in a high temperature furnace and heated to $800^{\circ} \mathrm{C}$. After about 15 minutes interval the temperature of the sample is raised at an increment of $50^{\circ} \mathrm{C}$ during each interval the shape of the cone is observed. The temperature range at which the initial rounding off or bending of the apex of the cone is observed can be termed as 'ash deformation temperature'. As the temperature is further increased, the same sample has a tendency to fuse into a hemispherical lump. The temperature range during which the phenomenon is observed can be taken as 'ash fusion temperature.'

\section{Calorific value}

According to the ASTM D 3286 standard, the Bomb calorimeter was used for determination of calorific value of the biomass. The biomass in the form of briquette was placed in a closed bomb and the bomb was filled with oxygen at pressure of 25 Atmosphere and placed in the bucket full of water. 
Table 1: Physical and thermal Properties of fresh feedstocks and their briquettes

\begin{tabular}{lccccc}
\hline Biomass Species & $\begin{array}{c}\text { Volatile } \\
\text { Matter } \\
\text { (\%,d.b.) }\end{array}$ & $\begin{array}{c}\text { Ash } \\
\text { Content } \\
\text { (\%,d.b.) }\end{array}$ & $\begin{array}{c}\text { Fixed } \\
\text { carbon, } \\
\text { (\%,d.b.) }\end{array}$ & $\begin{array}{c}\text { Calorific } \\
\text { value, } \\
\text { kcal/kg }\end{array}$ & $\begin{array}{c}\text { Bulk } \\
\text { density, } \\
\text { kg/m }\end{array}$ \\
\hline Feedstocks in loose form & & & & & \\
Saw Dust & 84.54 & 1.95 & 13.49 & 4707 & 240 \\
Sugarcane baggase & 90.36 & 1.95 & 7.67 & 4046 & 133 \\
Groundnut shell & 80.90 & 3.27 & 15.82 & 4898 & 255 \\
Jatropha Shell & 71.02 & 17.09 & 11.88 & 3618 & 288 \\
50\% RHP + 50\% Saw Dust & 74.67 & 10.69 & 14.63 & 4250 & 248 \\
Chopped Rice Straw & 77.89 & 17.43 & 4.66 & 3473 & 50 \\
Chopped Wheat Straw & 85.73 & 8.80 & 5.46 & 4021 & 50 \\
Cotton Stalk & 79.53 & 7.05 & 13.40 & 4077 & 226 \\
Feedstocks in briquettes form & & & & & 615 \\
Saw Dust & 76.10 & 3.95 & 19.95 & 4370 & 675 \\
Sugarcane Baggase & 76.12 & 4.52 & 19.36 & 3983 & 675 \\
Groundnut shell & 77.37 & 3.75 & 18.88 & 4011 & 680 \\
Jatropha Shell & 71.05 & 19.83 & 9.12 & 3526 & 685 \\
50\% RHP + 50\% Saw Dust & 72.28 & 11.98 & 15.74 & 4036 & 625 \\
Chopped Rice Straw & 64.44 & 19.47 & 16.09 & 3468 & 590 \\
Chopped Wheat Straw & 75.95 & 11.75 & 12.3 & 3926 & 591 \\
Cotton Stalk & 76.92 & 9.86 & 13.22 & 3898 & 631 \\
\hline
\end{tabular}

Table 2 : EMC of different feed stocks and their briquettes at different RH levels

\begin{tabular}{|c|c|c|c|c|c|c|c|}
\hline \multicolumn{2}{|c|}{ Sr. No } & \multicolumn{6}{|c|}{ Biomass SpiecesEMC at different Relative humidity levels } \\
\hline & & $40 \%$ & $50 \%$ & $60 \%$ & $70 \%$ & $80 \%$ & $90 \%$ \\
\hline \multicolumn{8}{|c|}{ Feedstocks in loose form } \\
\hline 1 & Saw Dust Powder & 2.20 & 4.19 & 5.96 & 6.74 & 8.67 & 12.16 \\
\hline 2 & Sugarcane baggase powder & 2.69 & 4.98 & 5.89 & 7.34 & 9.35 & 12.82 \\
\hline 3 & Groundnut shell powder & 3.65 & 4.49 & 6.46 & 6.90 & 9.86 & 12.71 \\
\hline 4 & Jatropha Shell powder & 5.89 & 6.78 & 8.85 & 10.83 & 15.23 & 20.30 \\
\hline 5 & $50 \%$ RHP + 50\% Saw Dust & 2.41 & 3.44 & 4.99 & 6.35 & 8.13 & 11.23 \\
\hline 6 & Chopped Rice Straw & 3.54 & 4.72 & 5.52 & 7.89 & 10.17 & 14.64 \\
\hline 7 & Chopped Wheat Straw & 2.63 & 3.33 & 5.86 & 8.02 & 10.73 & 17.45 \\
\hline 8 & Cotton Stalk Powder & 1.87 & 3.83 & 4.70 & 6.74 & 9.10 & 15.25 \\
\hline \multicolumn{8}{|c|}{ Feedstocks in briquettes form } \\
\hline 9 & Saw Dust & 1.66 & 2.90 & 4.03 & 5.15 & 7.28 & 9.60 \\
\hline 10 & Sugarcane Baggase & 2.01 & 3.40 & 4.20 & 5.39 & 7.43 & 9.80 \\
\hline 11 & Groundnut shell & 3.09 & 3.30 & 4.00 & 5.16 & 7.44 & 9.37 \\
\hline 12 & Jatropha Shell & 3.69 & 5.75 & 6.48 & 7.39 & 11.61 & 16.31 \\
\hline 13 & $50 \%$ RHP + $50 \%$ Saw Dust & 2.00 & 2.83 & 3.99 & 5.28 & 7.21 & 10.19 \\
\hline 14 & Chopped Rice Straw & 3.15 & 3.99 & 4.45 & 5.80 & 8.35 & 11.36 \\
\hline 15 & Chopped Wheat Straw & 1.86 & 2.75 & 4.73 & 5.52 & 8.11 & 15.99 \\
\hline 16 & Cotton Stalk & 1.11 & 2.10 & 3.91 & 5.19 & 7.55 & 12.59 \\
\hline
\end{tabular}


The bomb get ignite with the help of nickel wire by supplying electricity. The initial temperature of water was noted and then the change in temperature was recorded for continuous 20 minutes with an interval of one minute. The maximum temperature rise was used for calculating the heat of combustion of sample mathematically it is represented as.

$$
\mathbf{H}=\frac{\mathrm{W} \times \mathbf{t}}{\mathrm{m}}
$$

Where,

$\mathrm{W}=$ Water equivalent of Calorimeter, $\mathrm{Cal} /{ }^{\circ} \mathrm{C}$

$\mathrm{t}=$ Rise in temperature, ${ }^{\circ} \mathrm{C}$

$\mathrm{H}=$ Calorific value of fuel

(Heat of combustion of material), $\mathrm{Cal} / \mathrm{g}$

$\mathrm{m}=$ Mass of sample burnt, $\mathrm{g}$

\section{Determination of Equilibrium Moisture Content}

To determine the equilibrium moisture content (EMC), 8 different types of oven dried

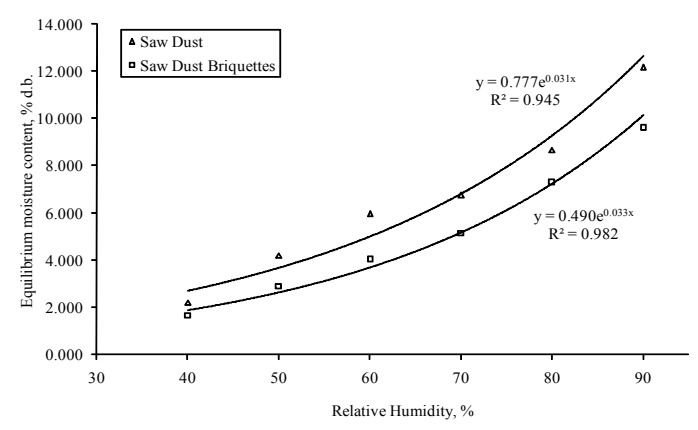

Fig. 1: Equilibrium moisture content of saw dust powder and their briquettes

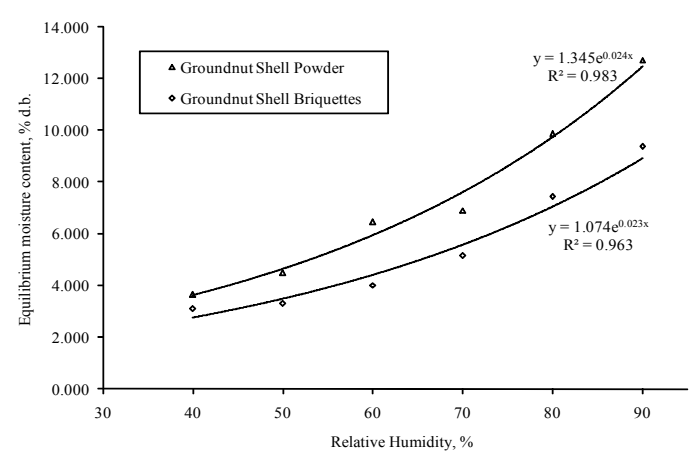

Fig. 3: Equilibrium moisture content of Groundnut shell powder and their briquettes biomass/ crop residues [sugarcane baggase, saw dust, groundnut shell powder, Jatropha shell powder, chopped rice straw, chopped wheat straw and $50 \%$ Rice husk powder (RHP)+ $50 \%$ saw dust(SD) and cotton stalk powder] and their briquettes were used for the study. Physical and thermal properties of the fresh feedstocks and their briquettes used in the study are shown in Table 1. EMC determination were undertaken during the months of January to August, when the temperature variation were in the range of $25-37 \stackrel{\circ}{\circ}$, at seven levels of relative humidity viz $40,50,60,70,80$ and $90 \%$. The selection of temperature and relative humidity were based on the maximum and minimum variation of temperature and relative humidity obtained in and around Vallabh Vidyanagar (Singh et.al 2001). The moisture content determinations were undertaken by using standard hot air oven method (ASTM 1983).

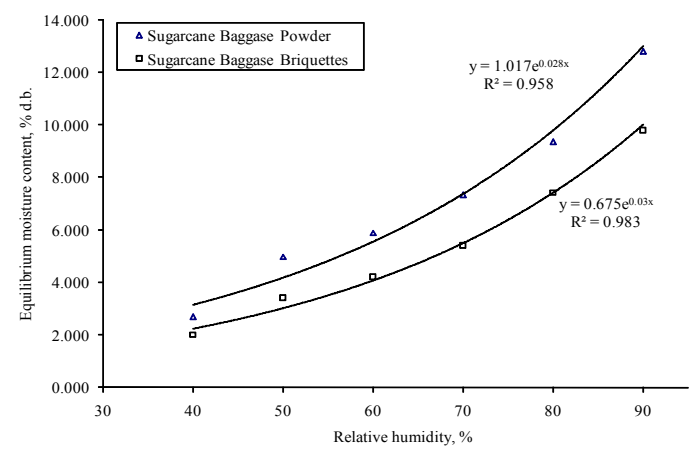

Fig. 2: Equilibrium moisture content of sugarcane baggase powder and their briquettes

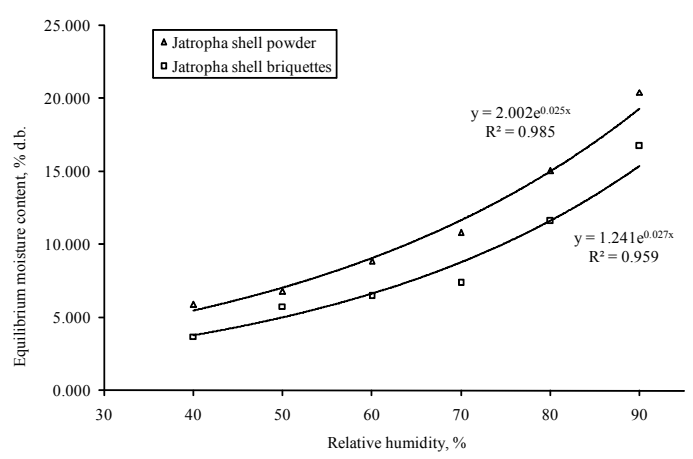

Fig. 4: Equilibrium moisture content of jatropha shell powder and their briquettes 


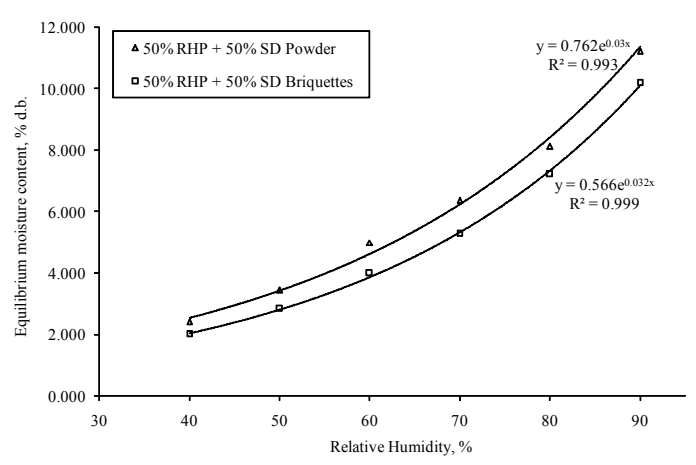

Fig. 5: Equilibrium moisture content of $50 \%$ RHP +50\% SD powder and their briquettes

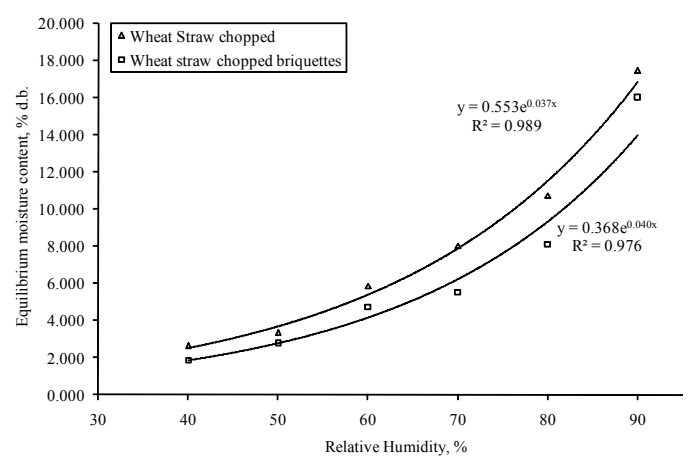

Fig. 7: Equilibrium moisture content of Wheat straw chopped and their briquettes

The EMC of the samples for each level of humidity was calculated using the following equation (Singh et.al. 2004)

$$
\operatorname{EMC}(\%)=\left[\left(W_{1}-W_{2}\right) / W_{2}\right] \times 100
$$

where,

$W_{1}=$ Weight of the biomass when constant weight was achieved at different $\mathrm{RH}(\mathrm{g})$

$W_{2}=$ Weight of the dry matter of the biomass $(\mathrm{g})$

\section{RESULTS AND DISCUSSION}

EMC of biomass feedstocks as saw dust powder, sugarcane baggase powder, jathropha shell powder , $50 \%$ rice husk powder $+50 \%$ saw dust powder, chopped rice straw, chopped wheat straw and cotton stalk powder was compared with their briquettes at 40 to $90 \% \mathrm{RH}$ (Fig. 1 to 8 ). In all cases, no significant difference in EMC was noticed at relative humidity values up to $70 \%$. At higher

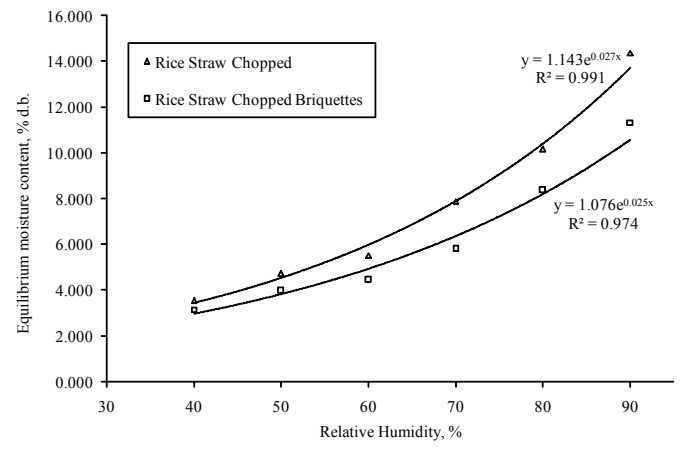

Fig. 6: Equilibrium moisture content of Rice straw chopped and their briquettes

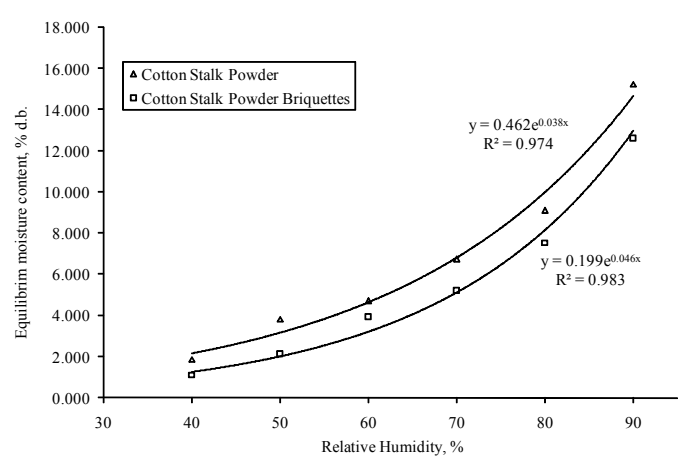

Fig. 8: Equilibrium moisture content of cotton stalk powder and their briquettes

$\mathrm{RH}$, above $70 \%$, the EMC of briquettes was $2-4$ $\%$ lower as compared to their feedstocks. This was due to more porous space in case of loose biomass compared to their briquettes. This characteristic is advantageous from the point of storage, as the briquettes will absorb less moisture from the atmosphere as compared to their feedstock.

\section{CONCLUSIONS}

Studies on equilibrium moisture content of feedstock and their briquette showed that the EMC of briquettes were lower than their feedstock at all the $\mathrm{RH}$ levels. It was lower by about $1-2.5 \%$ upto $70 \%$ $\mathrm{RH}$ and $2-4 \%$ when the $\mathrm{RH}$ was above $70 \%$. Due to lower $\mathrm{RH}$ the storage of briquettes was considered advantageous than their feedstock in loose form as the briquettes will absorb less moisture from the atmosphere at very high $\mathrm{RH}$ levels. The shape of the briquettes was found intact during storage even at 
$90 \% \mathrm{RH}$. At higher $\mathrm{RH}$ levels the EMC of saw dust, sugarcane bagasse, groundnut shell and mixture of rice husk and saw dust in powder form as well as in briquetted form were much lower than the other four feed stocks studied under this investigation.

\section{REFERENCES}

1. American Society of Testing of Materials (ASTM), Annual Book of ASTM Standards. Philadelphia: ASTM 19103 (1983).

2. ASTM. Annual book of ASTM standards, Philadelphia: American society for testing of materials,; p. 19103 (1983).

3. ASTM International. ASTM standard E711-87, Standard test method for gross calorific value of refuse-derived fuel by the bomb calorimeter (2012).

4. Anon. http://www.mnre.gov.in/biomass power cogeneration.

5. Browning, B.L. Methods of Wood Chemistry, Intersci. Publ. New York, London, 1 (1967 ).

6. Demirbas, A., and A.H. Sachin, briquetting properties of biomass waste materials. Energy Sources, 26: 83-91 (2004).

7. Jenkins, BM, Baxter, LL, Miles Jr., TR, Miles, TR. Combustion properties of biomass. Fuel Process. Technol. 54: 17- 46(1998).

8. Khan, Z.R. To study physical and chemical properties of agricultural residues related to gasification. Unpublished B.Tech.Thesis. C.A.E.T. Dr.PDKV, Akola (1993).

9. Khardiwar Mahadeo, Anil Kumar Dubey, Dilip Mahalle, Shailendra Kumar, Study on Physical and Chemical Properties of Crop Residues Briquettes for Gasification, American Journal of Energy Engineering, 2(2): 51-58 (2014). doi: 10.11648/j.ajee.20140202.11

10. Oladeji, J.T. "Fuel Characterization of BriquettesProduced from Corncob and Rice Husk Resides". Pacific Journal of Science and Technology, 11(1):101-106 (2010).

11. Payne, F.A., Small scale combustion and stationary bed gasification status and research priorities, Transaction of ASAE, 29(5): 1477-1483 (1986).

12. Rabier, F, Temmerman, M, Bohm, T, Hartmann, $\mathrm{H}$, Jensen, PD, Rathbauer, J, Carrasco, J, Fernandez, M., Particle density determination of pellets an briquettes. Biomass Bioenergy 30: 954 - 963 (2006).

13. Srivastava, N.S.L. "Briquetting of Crop Residues with special reference to Cotton Stalk - Market potential in India ", organized by CIRCOT Mumbai, ICAC and CFC, at Nagpur during November 9- 11; PP;62 - 76 (2009).

14. Tripathi,A.K.,P.V.R.Iyer and Tarachand Khandpal. A techno-economic evaluation of biomass briquetteing in India.Biomass\&Bioenergy 14, no.5-6,pp 479-488 (1998).

15. Tayade, S.R. Evaluation of differentb briquette making for gasifier.Unpublished M.Tech. Thesis, PGI,Dr. PDKV, Akola (2009).

16. Wakchaure G. C. and Sharma, Physical quality of some biomass briquettes. J. Agril. Engg. 44(1) : 48-52 (2007). 